\title{
СТВОРЕННЯ ВИХІДНОГО МАТЕРІАЛУ ДЛЯ ГЕТЕРОЗИСНОЇ СЕЛЕКЦЇ̈ ЖИТА ОЗИМОГО З ПІДВИЩЕНИМ ВМІСТОМ КРОХМАЛЮ
}

О. О. Штефан , Д. К. Сгоров

Інститут рослинництва ім. В. Я. Юр’єва НААН

У 2008-2010 pр. проведений аналіз 82 сортозразків НЦГРРУ та 10 сортозразків робочої колекції лабораторії селекції і генетики жита озимого Інституту рослинництва ім. В. Я. Юр'єва НААН на вміст крохмалю в зерні. Виділено сорти та гібридні комбінації з високим коефіцієнтом гетерозису, підвищеною урожайністю та виходом крохмалю з одиниці площі.

Жито озиме, сорт, гібрид, гетерозис, крохмаль

Жито - одна з основних зернових культур України, яка по використовуванню у виробництві хліба займає друге місце. Грунтово-кліматичні умови країни сприятливі для вирощування жита як самої холодостійкої зернової культури, не дуже вибагливої до родючості грунту [1,5]. Проблема забезпечення харчової промисловості сировиною, яка містить крохмаль, є актуальною в теперішній час. Сучасні гібриди жита озимого мають потенціал урожайності на рівні $8-10$ т/га та вміст крохмалю $62-65 \%$. Це обумовлює високу кількість збору крохмалю з одиниці площі, при низької собівартості продукції [3]. При порівнянні витрат на виробництво зерна пшениці озимої, ячменю чи кукурудзи, собівартість жита озимого набагато нижча $[2,4]$.

Вміст крохмалю в зразках колекції жита озимого коливається в межах $55-65 \%$. Тому створення нового вихідного матеріалу для селекції жита озимого на гетерозис, який би поєднував комплекс господарсько-цінних ознак з високим вмістом крохмалю $є$ актуальною задачею.

Мета роботи. Вивчити закономірності успадкування кількісних та якісних ознак вмісту крохмалю в зерні жита озимого. Створити вихідний матеріал для гетерозисної селекції жита озимого на основі ЦЧС, з комплексом господарсько корисних ознак та підвищеним вмістом крохмалю в зерні.

Матеріали та методики проведення досліджень. Матеріалом для роботи була колекція сортозразків жита озимого НЦГРРУ - 82 сортозразки та робоча колекція лабораторії селекції і генетики жита озимого Інституту рослинництва ім. В. Я. Юр'єва НААН - 10 сортозразків.

Вміст крохмалю в зерні визначали поляриметричним методом Еверса, фракційний склад крохмалю - йодометричним методом Джуліано.

(C) О. О. Штефан , Д. К. Єгоров. 2013. ISSN 0582-5075. Селекція і насінництво. 2013. Випуск 103. 
Польові дослідження проводили в лабораторії селекції і генетики озимого жита на дослідному полі Інституту рослинництва ім. В. Я. Юр'єва НАAН у 2008-2010 pp. Попередник - чорний пар. Об'єкти досліджень - сорти жита озимого Хамарка, Харківське 98, Стоір, Діхар, Хасто, Харківське 88, Таловская 15, Пам'ять Худоєрка, стерильні лінії $\mathrm{F}_{1}$ ЧС (90691А / 961358Б), $\mathrm{F}_{1}$ ЧС (90691А / 120337Б). Облікова площа ділянок 10 м², повторність триразова.

У 2008 р. в лабораторії генетики, біотехнології та біосировини Інституту рослинництва ім. В. Я. Юр'єва НААН проведено аналіз колекції сортозразків жита озимого Національного центру генетичних ресурсів рослин України та робочої колекції лабораторії селекції і генетики жита озимого (рис 1). Встановлено, що в колекції сортозразків жита озимого показник вміст крохмалю в зерні становив від 52,6\% до 65,6 \%.

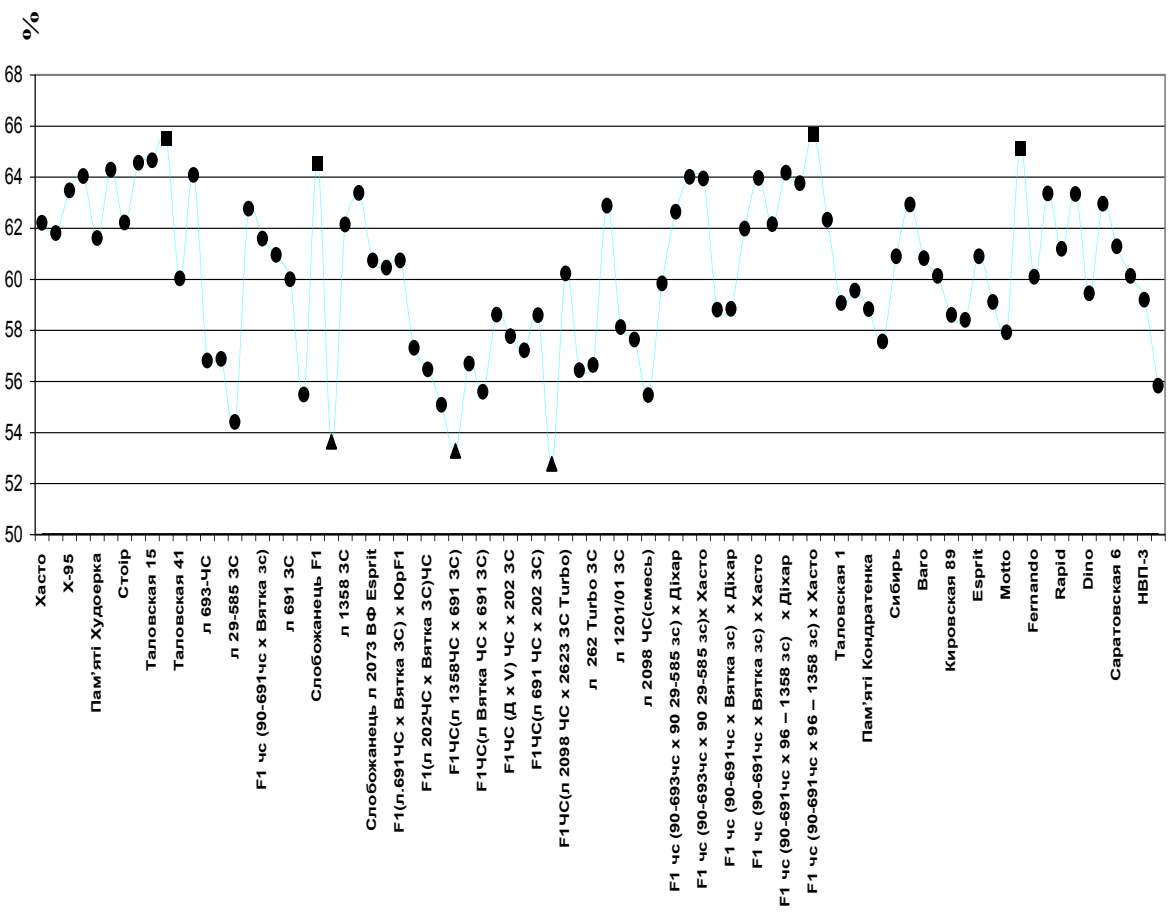

Сортозразки

Рис 1. Вміст крохмалю в зерні сортозразків жита колекції НЦГРРУ .

Найбільш високі показники спостерігали у сортів Хасто, Стоір, Таловска 15, Харківське 98 - (62,21\%, 62,22 \%, 64,65 \%, 64,28 \%) відповідно, в сортозразках Слобожанець $\mathrm{F}_{1}, \mathrm{~F}_{1}$ ЧС (2098A / 2623B TurboБ), $\mathrm{F}_{1}$ ЧС (1358A / 202Б), л 29-585А - вміст крохмалю не перевищував $54 \%$. 
У 2009-2010 рр. виділено 10 сортозразків жита озимого з високою урожайністю та підвищеним вмістом крохмалю в зерні для проведення тестерних схрещувань. Поведено аналіз батьківських форм та материнських ліній жита озимого на вміст крохмалю, визначено урожайність та вихід крохмалю з одиниці площі (табл. 1).

Таблиця 1

Урожайність, вміст та вихід крохмалю з батьківських компонентів жита озимого

\begin{tabular}{|c|c|c|c|c|c|c|}
\hline \multirow[t]{2}{*}{ Сортозразки } & \multicolumn{2}{|c|}{$\begin{array}{l}\text { Вміст крох- } \\
\text { малю, \% }\end{array}$} & \multicolumn{2}{|c|}{$\begin{array}{c}\text { Урожайність, } \\
\text { т/га }\end{array}$} & \multicolumn{2}{|c|}{$\begin{array}{c}\text { Вихід крохма- } \\
\text { лю, т/га }\end{array}$} \\
\hline & $2009 \mathrm{p}$. & $2010 \mathrm{p}$. & $2009 \mathrm{p}$. & $2010 \mathrm{p}$. & 2009 p. & $2010 \mathrm{p}$ \\
\hline Харківське 98 & 64,28 & 61,21 & 8,3 & 5,1 & 5,0 & 3,5 \\
\hline Хамарка & 61,80 & 58,28 & 7,9 & 6,1 & 4,8 & 3,5 \\
\hline Пам’ять Худоєрка St. & 61,61 & 58,81 & 7,9 & 5,8 & 5,8 & 4,3 \\
\hline Хасто & 62,21 & 56,87 & 7,9 & 5,8 & 5,1 & 3,8 \\
\hline Стоір & 62,22 & 55,99 & 8,3 & 6,0 & 5,1 & 3,3 \\
\hline Діхар & 54,30 & 52,12 & 8,5 & 7,9 & 4,7 & 3,9 \\
\hline Таловская 15 & 55,18 & 54,43 & 8,7 & 8,2 & 5,0 & 3,2 \\
\hline Харківське 88 & 53,73 & 53,42 & 7,6 & 6,8 & 4,3 & 3,3 \\
\hline $\begin{array}{l}\mathrm{F}_{1} \text { ЧC (90691A / } \\
961358 \mathrm{~b})\end{array}$ & 55,47 & 54,26 & 8,6 & 7,8 & 5,2 & 4,7 \\
\hline $\begin{array}{l}\mathrm{F}_{1} \text { ЧC (90691A / } \\
120337 \mathrm{~B})\end{array}$ & 53,92 & 53,45 & 7,4 & 6,9 & 4,3 & 3,8 \\
\hline $\mathrm{HIP}_{0,05}$ & 2,1 & 2,2 & 0,2 & 0,19 & 0,1 & 0,09 \\
\hline
\end{tabular}

Серед використаних у схрещуваннях батьківських форм експериментальних гібридів найвищі показники урожайності та вмісту крохмалю (відповідно і виходу крохмалю з одиниці площі) мали сорти Харківське 98, Хасто, лінія $\mathrm{F}_{1}$ ЧС (90691A / 961358Б). Сорти: Стоір, Таловская 15, Діхар, лінія $\mathrm{F}_{1}$ ЧС (90691A / 120337Б) за урожайністю та виходом крохмалю суттево не відрізнялись, але показник вміст крохмалю в зерні на 7-9 \% був нижче ніж у інших сортозразках (див. табл. 1).

Проведено аналіз батьківських компонентів, материнських ліній і нових експериментальних гібридів на вміст крохмалю в зерні та виходу з одениці площі (табл. 2). Встановлення характеру успадкування ознаки підвищений вміст крохмалю проведено в системі тестерних схрещувань 3 залученням двох тестерів, контрастними за вмістом крохмалю в зерні.

Аналіз батьківських компонентів та експериментальних гібридів за урожайністю в 2009-2010 роках виявив, що найвищі показники урожайності мали сорти Харківське 98, Хасто, Пам'ять Худоєрка (стандарт), гібриди $\mathrm{F}_{1}$ ЧС (90691A / 120337Б) / Хасто, F ЧС (90691A / 961358Б) / Діхар, F $F_{1}$ ЧС (90691А / 961358Б) / Хасто. 
Таблиця 2

Вміст крохмалю в зерні, урожайність батьківських компонентів та експерементальних гібридів жита озимого

\begin{tabular}{|c|c|c|c|c|}
\hline \multirow[t]{2}{*}{ Сортозразки } & \multicolumn{2}{|c|}{$\begin{array}{l}\text { Вміст крохма- } \\
\text { лю, \% }\end{array}$} & \multicolumn{2}{|c|}{$\begin{array}{l}\text { Урожайність, } \\
\text { т/га }\end{array}$} \\
\hline & 2009 p. & $2010 \mathrm{p}$. & $2009 \mathrm{p}$. & $2010 \mathrm{p}$. \\
\hline Харківське 98 & 64,28 & 61,21 & 8,3 & 5,1 \\
\hline Хамарка & 61,80 & 58,28 & 7,9 & 6,1 \\
\hline Пам'ять Худоєрка (стандарт) & 61,61 & 58,81 & 7,9 & 5,8 \\
\hline Хасто & 62,21 & 56,87 & 7,9 & 5,8 \\
\hline Стоір & 62,22 & 55,99 & 8,3 & 6,0 \\
\hline Дixap & 54,30 & 52,12 & 8,5 & 7,9 \\
\hline Таловская 15 & 55,18 & 54,43 & 8,7 & 8,2 \\
\hline Харківське 88 & 53,73 & 53,42 & 7,6 & 6,8 \\
\hline $\mathrm{F}_{1}$ ЧC (90691A / 961358Б) & 55,47 & 54,26 & 8,6 & 7,8 \\
\hline $\mathrm{F}_{1}$ ЧC (90691A / 120337Б) & 53,92 & 53,45 & 7,4 & 6,9 \\
\hline $\mathrm{F}_{1}$ ЧC (90691A / 120337Б) / Стоір & 58,80 & 57,79 & 9,8 & 8,7 \\
\hline $\mathrm{F}_{1}$ ЧC (90691A / 120337Б) / Дiхар & 58,84 & 56,69 & 10,6 & 9,2 \\
\hline F ЧC (90691A / 120337Б) / Хамарка & 61,98 & 56,99 & 10,4 & 9,3 \\
\hline $\mathrm{F}_{1}$ ЧС (90691A / 120337Б) / Хасто & 63,96 & 56,61 & 9,7 & 8,8 \\
\hline F & 60,63 & 59,29 & 10,2 & 9,3 \\
\hline F ЧС (90691A / 120337Б) / Харківське 88 & 64,58 & 64,04 & 8,6 & 7,9 \\
\hline $\begin{array}{l}\mathrm{F}_{1} \text { ЧС (90691A / 120337Б) / Пам’ять } \\
\text { Худоєрка }\end{array}$ & 61,61 & 60,57 & 10,3 & 9,9 \\
\hline $\mathrm{F}_{1}$ ЧС (90691A / 120337Б) /Харківське 98 & 64,28 & 62,56 & 9,6 & 8,5 \\
\hline $\mathrm{F}_{1}$ ЧC (90691A / 961358Б) / Стоір & 64,15 & 59,62 & 10,8 & 10,2 \\
\hline F ЧC (90691A / 961358Б) / Дixap & 63,17 & 57.62 & 10,6 & 9,8 \\
\hline $\mathrm{F}_{1}$ ЧC (90691A / 961358Б) / Хамарка & 64,75 & 58,33 & 10,3 & 8,7 \\
\hline $\mathrm{F}_{1}$ ЧС (90691A / 961358Б) / Хасто & 65,68 & 56,62 & 9,9 & 8,7 \\
\hline F ЧС (90691А / 961358Б) / Таловская 15 & 62,43 & 61,68 & 10,0 & 9,6 \\
\hline F ЧС (90691А / 961358Б) / Харківське 88 & 63,29 & 62,35 & 8,3 & 7,8 \\
\hline $\begin{array}{l}\mathrm{F}_{1} \text { ЧС (90691A / 961358Б) / Пам’ять } \\
\text { Худоєрка }\end{array}$ & 65 & 9 & 10,5 & 10,2 \\
\hline F ЧС (90691A / 961358Б) /Харківське 98 & 59,62 & 60,08 & 10,2 & 9,6 \\
\hline
\end{tabular}

В окремих гібридів гетерозис складає більш ніж $200 \%: \mathrm{F}_{1}$ ЧС (90691A / 120337Б) / Пам’ять Худоєрка (205 \%), $\mathrm{F}_{1}$ ЧС (90691A / 120337Б) / Харківське-88 (205\%), F ЧС (90691А / 961358Б) / Таловска 15 (230\%).

Найвищі показники ознаки вміст крохмалю в зерні за дворічними даними відмічається в сортах Харківське 98, Стоір, Пам’ять Худоєрка.

У гібридних комбінаціях коефіцієнт гетерозису становив до 10,9\%: $\mathrm{F}_{1}$ ЧС (90691A / 961358Б) / Харківське 98 (5,1%), $\mathrm{F}_{1}$ ЧС (90691A / 961358Б) 
/ Пам’ять Худоєрка (5,6 \%), F 1 ЧС (90691A / 120337Б) / Стоір (10,8 \%), $\mathrm{F}_{1}$ ЧС (90691А / 120337Б) / Хамарка (10,9\%).

Висновки. Встановлено, що в сортозразках жита озимого колекції НЦГРРУ існує різноманіття за ознакою вміст крохмалю в зерні. Показана можливість сворення гібридів з комплексом господарсько цінних ознак та підвищеним вмістом крохмалю в зерні за участі батьківських компонентів : Хамарка, Харківське 98, Стоір, Діхар, Хасто, Харківське 88, Таловская 15, Пам'ять Худоєрка (стандарт).

Стерильних лінії $\mathrm{F}_{1}$ ЧС (90691А / 961358Б), $\mathrm{F}_{1}$ ЧС (90691А / 120337Б).

\section{Список використаних джерел}

1. Сгоров Д. К. Особливості гетерозисної селекції жита озимого / Д. К. Сгоров, В. П. Дерев'янко // Селекція і насінництво. - 2004. -Вип. 88-С. 40-45.

2. Кобылянский В. Д. Исследования ржи и их связь с задачами селекции / В. Д. Кобылянский // Вестник сельскохозяйственной науки. - 1987. - № 11. - С. 36-40.

3. Дерев'янко В. П. Генетичні аспекти створення вихідного матеріалу для гетерозисної селекції жита озимого / В. П. Дерев'янко, Г. К. Адамчук, В. М. Плехтяк. // Селекція і насінництво.- Київ :Урожай, 1993. - Вип. 74 C. 54-58.

4. Дерев'янко В. П. Селекція гібридів жита озимого / В. П. Дерев'янко // Селекція і насінництво. - Харків, 2000. - Вип. 84 - С. 35-39.

5. Кобылянский В. Д. Комбинационная способность стерильных линий озимой ржи в системе топкроссных скрещиваний / В. Д. Кобылянский, Н. С. Лапиков, А. Г. Катерова, Т. Т. Ерошенко // НТБ института растениеводства. - Л., 1987. - Вып. 169. - С. 3-8. 